\title{
中国の山西省におけるAMSR-E土壤水分の 時空間変動に関する研究
}

孫玫 1）艾 麗坤 2）開發一郎 3） 藤井 秀幸 4）近藤 昭彦 5)

1) 千葉大学大学院理学研究科

(₹ 263-0022 千葉県千葉市稲毛区弥生町 1-33)

2) 中国科学院大気物理研究所

( ₹ 100029 中国北京市朝阳区华严里 40 号)

3) 広島大学大学院総合科学研究科

（７７39-8521広島県東広島市鏡山 1-7-1）

4）一般財団法人リモート・センシング技術センター

（テ 105-0001 東京都港区虎)門3-17-1 TOKYU REIT 虎)門ビル3階）

5) 千葉大学環境リモートセンシング研究センター

（テ263-0022 千葉県千葉市稲毛区弥生町1-33）

乾燥・半乾燥地域における土壤水分は地表面の熱収支変化, 気候変化などと関連する重要な水文要素である. 近 年, 衛星リモートセンシングを用いて, 広域を対象とした長期間の土壤水分を観測することが可能となり, 改良型 マイクロ波放射計（AMSR-E）による土壤水分の広域・時系列データが利用できるようになった，そこで，本研究は 中国の山西省において AMSR-E土壤水分の検証を行い, これと検証地の地表面の水文因子（降水量）や植生因子 （NDVI）との関連を調べることを目的とした．その結果, 108 カ所の地上観測地点のうち 64 カ所において AMSR-E土 壤水分と実測土壤水分との良い相関が得られた。相関係数が高い地点は, 1）十分な密度の地上観測地点がある地域, 2）土地利用夕イプが均一な地域，3）地形が相対的に平坦な地域であり，これらの条件を考慮することにより AMSR-E土䁃水分観測から広域の土壤水分変動をより正確に捉えることができることが明らかとなった

\section{キーワード：AMSR-E, 土壤水分, 降水量, 山西省}

\section{I 、はじめに}

地域に㧍いて，水・エネルギー循環に大きな影響 を与える要素の一つである土壤水分の推定はリモー トセンシングに課せられた重要な課題であり, 衛星 を用いたマイクロ波リモートセンシングは, 土壤水 分の広域情報収集のための有効な手段となっている (小池ほか, 2004).2002年に打ち上げられた米国の AQUA衛星に日本の改良型高性能マイクロ波センサ (AMSR-E : Advanced Microwave Scanning Radiometer for EOS）が搭載され，土壤水分を含む複数の水·工 ネルギー循環に関係する物理量をグローバルスケー ルで推定することができるようになった，AMSR-E に採用された直径 $1.6 \mathrm{~m}$ の大型アンテナは, これま で衛星に搭載された同種センサの中でも最大のもの であり, 従来の $2 \sim 3$ 倍の高い空間分解能を有し,
午後軌道に存在する唯一のマイクロ波放射計とし て, 全世界を9年5カ月間にわたり継続的に観測し た。また，広域かつ定量的な土壤水分分布，雲に影 響されない全天候型の海面水温分布等, これまでに ないデー夕が作成された（道浦, 2011）。

AMSR-E土壤水分推定の主なアルゴリズムには, アメリカ航空宇宙局 (NASA: National Aeronautics and Space Administration) の Njoku et al. (2003), 独 立行政人宇宙航空研究開発機構 (JAXA: Japan Aerospace eXploration Agency）の小池ほか（2004）, アメリカ合衆国農務省の Jackson（1993），アムステ ルダム自由大学とJAXAの共同研究による Owe et al.（2001）らのものがある. これらの土䁃水分推定 アルゴリズムは，JAXA-NASAの AMSR/AMSR-E合 同委員会での土壤水分のアルゴリズム評価会議にお 
いて，日本のAMSR-E土壤水分推定アルゴリズムが 最も高い精度で土壤水分の推定ができることが示さ れている (小池ほか, 2004)。このアルゴリズムを用 いた全球の土䁃水分マップが世界に公開されること になった。このデータはモンゴルにおける実測土壤 水分との比較により精度の検証が行われており, 半 乾燥地域のステップにおける土壤水分の時空間変動 を捉えることができた(小池ほか, 2004)。モンゴル 高原の草原に扔けるAMSR-E土壤水分の検証はその 後も継続して行われ，その精度の確認が行われてい るが（Kaihotsu et al., 2009），より実用的で高精度の 土壤水分の計測のためには, さらに多様な気候, 植 生, 水文環境のもとで検証がなされるべきである. しかし, 実際には連続的な地上土壤水分とその分布 の観測を実施している場所は少なく，またそのよう なデー夕の入手も容易ではない，そこで，本研究で は土壤水分の地上観測データが得られている中国の 山西省において, AMSR-E土壤水分との比較を行う と共に, AMSR-E土壤水分と降水量, および地形の 特徵, 植生指標, 土地利用等の地表面属性との関連 性を明らかにすることを目的とする。

\section{II. 解析対象領域とデータ}

\section{1. 解析対象地域の概要}

中国の山西省（Shanxi Province）は11市から構成 され, 東経 $110.14^{\circ} \sim 114.33^{\circ}$, 北緯 $34.34^{\circ} \sim 40.43^{\circ}$ に 位置している，北は万里の長城と内モンゴル，東は 太行山脈と河北省, 南と西は黄河, 河南省と陝西省 によって囲まれている，東西約 $370 \mathrm{~km}$, 南北約 670 $\mathrm{km}$, 総面積は $156,266 \mathrm{~km}^{2}$ であり, 中国の総面積の $1.64 \%$ を占める。標高は $171 〜 3,072 \mathrm{~m}$ の範囲にあり (図一1), 黄土高原など黄土に覆われた山地や丘陵 などの高地が省面積の 80 \%を占めている。 その中 に平坦地として北部の Datong 盆地とXinding 盆地, 中部の Taiyuan盆地, 南部のLinfen盆地, Yuncheng 盆地と Changzhi 盆地が存在している. 山西省全域に 抒ける気候は大陸性の温帯モンスーン気候に属し, 年平均気温は $6.4{ }^{\circ} \mathrm{C}$ で, 年較差が大きく, 最寒月の 1 月の月平均気温は $-11.3{ }^{\circ} \mathrm{C}$, 最暖月の 7 月の月平均 気温は $21.8{ }^{\circ} \mathrm{C}$ である. 全域の年降水量は $400 \sim 650$ $\mathrm{mm}$ である(牛ほか, 2008). 山西省には山地, 平地 と盆地など複雑な地形を含み, 衛星計測による土壤 水分分布の解析のためには地表面の多様な属性の理 解を前提とする必要がある。

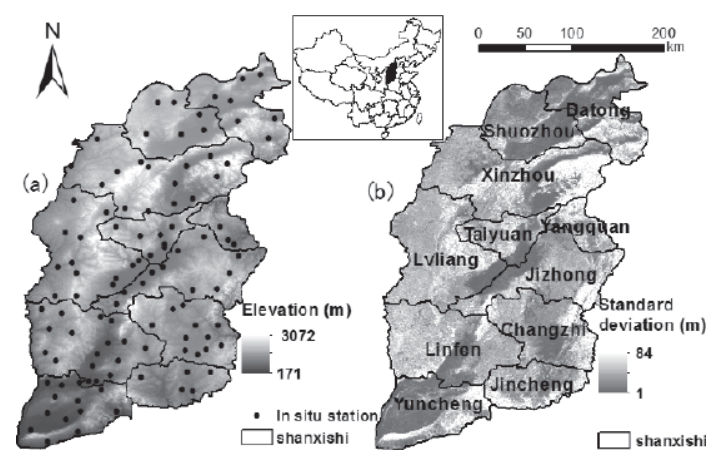

図 - 1 土壤水分の地上観測地点と解析対象地域の標高 (a) および標高の標準偏差（b)，ここで標準偏 差は $1 \mathrm{~km} \times 1 \mathrm{~km}$ の空領域における $30 \mathrm{~m}$ 空間分 解能の標高值の標準偏差であり, 地形の複雑さ を表す

Fig. 1 In situ soil moisture station and elevation of study area (a), and standard deviation (b) of 30 m-resolution DEM in a $1 \mathrm{~km} \times 1 \mathrm{~km}$ window area that represents the complexity of the terrain.

\section{2. 使用データの概要}

\section{1) AMSR-E土潩水分}

AMSR-Eは,JAXAが開発し, NASAの地球観測衛 星AQUAに搭載されたマイクロ波放射計であり，複 数の水・エネルギー循環に関するデー夕を収集する ことが可能なセンサである. AMSR-Eは地球表面お よび大気から放射される微弱なマイクロ波帯の電波 を多周波・多偏波で測定できる. AMSR-Eはマイク 口波を用いているため, 夜間や雲が出ている状況で も地表観測ができるメリットがある.

AMSR-Eによって測定された輝度温度から, ISW (Index of Soil Wetness) と PI (Polarization Index) の 二つの指数を計算し, ルックアップテーブルにより, 土潩水分を推定することができる(小池ほか, 2000）。本研究では, 小池ほか（2000）の改良アル ゴリズム（Ver.5.31）による下降軌道の AMSR-E土壤 水分データを利用した。 この土壤水分データプロダ クトに格納されている土塞水分は体積含水率 $\left(\mathrm{m}^{3} /\right.$ $\mathrm{m}^{3}$ ) である。空間分解能（フットプリント）が約 50 $\mathrm{km}$ 四方のデータを 0.1 。 (約 $10 \mathrm{~km})$ グリッドにリサ ンプリングし，格納している. 2002年6月から 2010 年 5 月までのデータが日単位で利用可能である.

\section{2）地上観測データ}

中国科学院大気物理研究所による山西省に求ける 109 地点（図ー1）の地上観測データを使用した。こ のデータには各観測地点の緯度, 経度, 標高, 土壌 
水分が含まれている. 土壤水分の測定方法は炉乾燥 法であり, 深度 $0 \sim 10 \mathrm{~cm}$ の土壤を採取し, 土壤水 分 (体積含水率 $\left.\mathrm{m}^{3} / \mathrm{m}^{3}\right)$ を測定している。観測期間 は2006年と 2007 年の 4 月 28 日から 9 月 18 日であり, 10 日ごとに日付の 1 の位が 8 の日に測定がなされて いる.

\section{3）降水量データ}

総合地球環境学研究所によるAPHRODITE's Water Resources (Asian Precipitation-Highly Resolved Observational Data Integration Towards Evaluation of the Water Resources）プロジェクトは, 雨量計観測によ る日降水量データを収集して，アジア地域に㧍ける 高空間分解能の日降水量グリッドデータを作成する ことを目的としている. APHRODITE降水量データ は地上観測デー夕を空間的に内挿することにより作 成し, 公開された（Yatagai et al., 2009 ; Yatagai et al., 2012)。本研究で用いたデー夕は2006年と 2007 年の モンスーンアジア領域の $0.25^{\circ}$ の空間分解能の日降 水量プロダクト（バージョンV1003R1）である.

\section{4）植生指標}

植生指標は, 植物による光の反射の特徴に基づき, 衛星デー夕を使って簡易な計算式で地表面の植生の 状況を把握することを目的として考案された指標で あり，植生の量や活力を表している。代表的な植生 指標には, NDVI（Normalized Difference Vegetation Index）がある。植物の生育と土壤水分には一定の関 係性があるため (Njoku et al., 2003)，本研究では SPOT IMAGE社が運用しているSPOT衛星に搭載さ れたVEGETATIONセンサによって撮影された赤お よび近赤外画像から作成されたNDVIデー夕を用い て山西省の植生の時空間変動とその土䁃水分との関 係について検討を行った。このデータはVITO (Flemish Institute for Technological Research) がイン ターネットで公開しているデータで, 等緯度経度グ リッド（約 $1 \mathrm{~km}$ 空間分解能）にリサンプリングされ た10日ごとにコンポジットされたNDVI值が格納さ れている。

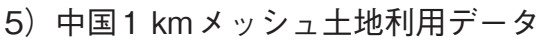

「中国国家資源環境のリモートセンシングマクロ調 查と動態研究」と「国家基本資源・環境のリモート センシング情報動態サービス体系の設立」の2つの プロジェクトにより作成された $1 \mathrm{~km}$ 空間分解能の土
地利用データである。このデータは 25 個の空間レイ ヤから構成され, 各々のレイヤは 1 種類の土地利用 タイプ（中国国家標準 GB/T21010-2007）の空間分布

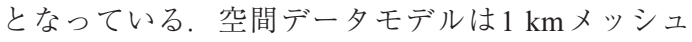
データで, 各レイヤの值は $1 \mathrm{~km}^{2}$ のメッシュの範囲に 占める当該土地利用クラスの面積率（\%）として格 納されている。この百分率は 100 万分の 1 土地利用べ クターデータの面積属性の統計から得られたもので ある。デー夕は 1980 年代と 2000 年代の 2 時期がある. 本研究では土壤水分の観測期間と合わせて, 最新の 2000 年代の土地利用データを使用し, 山西省におけ る主な分類項目の土地利用分布を主題図化した。

\section{6) ASTER GDEM標高データ}

研究対象地域をカバーするDEM (Digital Elevation Model）として, 経済産業省が米国航空宇宙局 （NASA）と共同運用している衛星搭載型地球観測光 学センサASTERにより取得した衛星画像デー夕か ら作成した「全球三次元地形データ ASTER GDEM (ASTER Global DEM)」を使用した. ASTER GDEM は北緯 83 度から南緯 83 度の間のほぼ全球の陸域を, 約22,600タイルでカバーしている. 各タイルは少な くとも $0.01 \%$ の地表面を含み, 等緯度経度座標にリ サンプリングされた $30 \mathrm{~m}$ の空間分解能のDEMであ る. ASTER GDEM標高データから標高を読み取る だけでなく, $1 \mathrm{~km} \times 1 \mathrm{~km}$ の空領域における標高の標 準偏差を求めることにより, 地形の複雑さを表す 2 次データを作成した。

\section{III. 研究手法}

\section{AMSR-E土壤水分と地上観測データの比較}

AMSR-E土畩水分を検証するために 108 地点（五 台山の地上観測デー夕は欠測）の地上観測データと の相関関係について検討を行った. AMSR-E土畩水 分データのフットプリントは約 $50 \mathrm{~km}$ 四方で, リサ ンプリングポイントの間隔は $10 \mathrm{~km}$ であるため, 本 研究では, $5 \times 5$ グリッド（約 $50 \mathrm{~km}$ 四方）の㝕領域 を選択した。この範囲に含まれる地上観測データの 平均值を計算し, 2006年, 2007年の各対象月の 8,18 , 28 日の衛星推定土壤水分デー夕を抽出し, 両者の相 関係数を求めた。

\section{AMSR-E土壤水分の時空間分布}

山西省では冬季は地表面が凍結し, 積雪があるた 
めAMSR-E土壤水分は実際の土壤水分を捉えていな い(小池ほか, 2004)。 よって, 以下の解析では無雪 期を対象とした。また，AMSR-E土壌水分は日単位 のデータであるが，軌道ごとの走査幅の制約で完全 にオーバーラップせず，データが久測する領域が存 在する.

乾燥・半乾燥地域では降水後, 短時間で地表面の 湿潤度が変動する（篠田, 2005）。瞬間值を捉えてい る衛星観測による土壤水分分布の特徴を抽出するた めに, 各月の最大值と旬の平均值を抽出して土壤水 分分布の特性解析に使用した。本研究では2003年か ら 2009年までの4月〜9月（無雪期と判断される） の各月の最大值の経年平均值と夏季（7月, 8 月, 9 月） の初旬の平均值を用いて, 土壤水分の時空間変動を 確認することにした。

\section{AMSR-E土壤水分と植生指標の関係}

植生の分布は地表面の土壤水分の変動に大きく影 響する（Njoku et al., 2003），植生の成長については 一般的に用いられるNDVIを利用し, 土壤水分との 関係について検討を行った。本研究では2006年およ び2007年の夏（7月, 8月と9月）の初旬における山 西省全域のNDVIの分布図を作成し, AMSR-E土壤 水分との分布を比較した。 また, SPOT/Vegetation画 像とAMSR-E土䁃水分データの空間分解能はそれぞ れ異なる。選択した $5 つ の$ 代表領域における 2 年間 の4月から9月の初旬について, SPOT/Vegetation NDVIピクセルの平均值とAMSR-E土壤水分初旬の 平均值（初旬で土壤水分デー夕の欠測日がある）を 求め, 両者の関係を比較した。

\section{IV. 結果打よび考察}

\section{AMSR-E土壤水分と実測值の比較}

冬季の積雪期を避けた 2006 年と 2007 年の 4 月 28 日から9月18日の地上で土壤水分が測定されている 日付を対象として, AMSR-E土壤水分と実測土壤水 分の相関係数の分布図（図一2）を作成した。全域 の相関係数は $0.05 \sim 0.96$ の範囲にあり, 2 年間連続し て相関係数の高い（0.70 以上）地点は中部の Taiyuan 盆地, 南部のLinfen盆地, Yuncheng盆地, Changzhi 盆地と Jincheng 地域, 東部の Yangquan 地域に分布し ている。図一3は土壤水分実測值が得られた 108 地 点におけるAMSR-E土畩水分との相関係数と標高お よび標高の標準偏差との関係を示す．高い相関係数

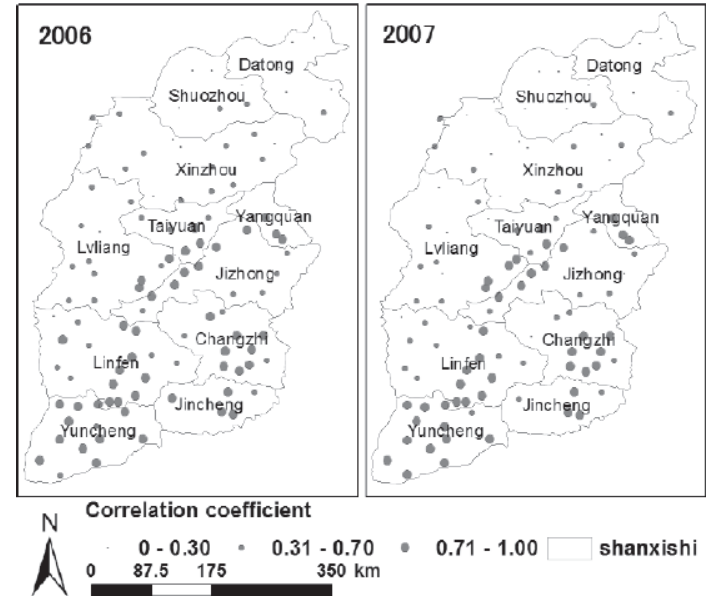

図－2 2006年および2007年の4月28日から9月18日 の AMSR-E土壤水分と実測土壤水分の相関係数 の分布

Fig. 2 Correlation coefficient between AMSR-E soil moisture and in situ soil moisture in 2006 and 2007(28 April to 18 September).

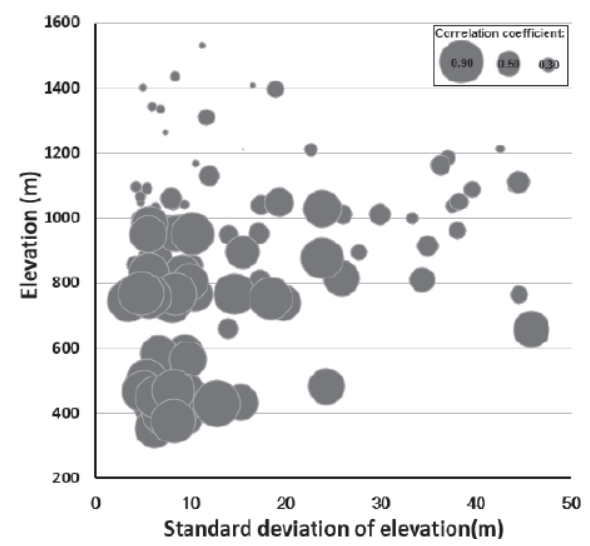

図－3 108 力所の地上観測地点におけるAMSR-E土壤 水分と実測土壤水分の相関係数と, 標高および 標高の標準偏差との関係

Fig. 3 Relation among correlation coefficient, elevation and standard deviation of elevation in 108 in situ stations.

は概ね標高 $1,000 \mathrm{~m}$ 以下，および標高の標準偏差が $20 \mathrm{~m}$ より 小さい領域に多く分布している。特に標高 が $400 \mathrm{~m} \sim 600 \mathrm{~m}$ と $800 \mathrm{~m} \sim 1,000 \mathrm{~m}$ のところに高い 相関係数（0.7以上）が集中している様に見えるが， それぞれ南部のLinfen盆地と Yuncheng盆地, および 中部の Taiyuan盆地に相当する. このことは, 広大 な平坦地ではAMSR-E土壤水分は実測土壤水分を良 く捉えていることを意味している。一方，相対的に 低い相関係数（ここでは 0.30 未満とした）地域の標 
高が $1,000 \mathrm{~m}$ 以上を示し, 標高の標準偏差が大きく, ほぼ山岳地域に相当している。このことはAMSR-E 土壤水分は地形の複雑さの影響を受けている可能性 を示唆している.

次に山西省全域から，標高，標高の標準偏差，平 均降水量と土地利用タイプが異なるため, 中部の Taiyuan と Yangquan 地域, 南部の Linfen と Changzhi 地域，および北部の Datong 地域から5つの代表領域 （aｅ）を選び，各地の属性を表一1に示した。 それ ぞれの領域（約 $50 \mathrm{~km}$ 四方）におけるAMSR-E土畩 水分と実測土壤水分を出し, 関係結果を図一 4 に示 した，各領域における両者のプロットは全体的に 1 ： 1 線の近くに分布する傾向が見える. AMSR-E土壤 水分が $10 \%$ を超えると実測土壤水分に対して過大 評価しているように見える。この現象はKaihotsu et al.（2009）でも指摘されているが，高含水量域では マイクロ波で検出できる土壤水分は極く浅い土壤層 中（約 1-2 cm 深度）の水分か地表面のものであるの に対して，地上観測データは地表面から 0-10 cm 深 度の平均值を計測している. AMSR-Eは降水後の地 表面の水分（植生表面の水分を含む）の影響を受け るため，結果として降水後AMSR-E土壤水分が実測

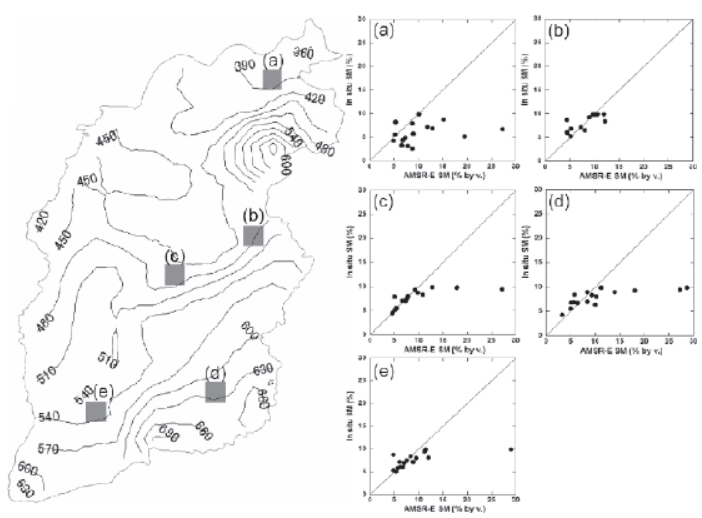

図 -4 年平均降水量の分布および代表的な $5 つ の$ 領域に おけるAMSR-E土壤水分と実測土壤水分の関係

Fig. 4 Average annual rainfall and relation of AMSR-E soil moisture to In situ soil moisture at five representative areas.
值に対して過大評価する傾向になると考えられる。 しかし，無降水時の代表的な土䁃水分の範囲では AMSR-E土壤水分と実測土䁃水分は良好な相関を示 している.

また, 5つの代表領域で地上観測地点の密度がそれ ぞれ違う。北部の $\mathrm{a}$ 領域では相関が 0.3 以下であった が, 疎らな地上観測地点の密度（平均 2 点 $/ 100 \mathrm{~km}^{2}$ ) である．地上観測地点同士の距離が遠いため, 約 50 $\mathrm{km}$ 四方の領域で平均した実測土壤水分にバイアス が生じたことが原因の一つとして考えられる。その ほかの4領域では地上観測地点の密度が高く（平均 5 点 $\left./ 100 \mathrm{~km}^{2}\right)$, 相関係数が $0.64 \sim 0.75$ になり，比較 的良い相関が認められた。地上観測地点の密度が十 分高い地点ではAMSR-Eは地表面の土壤水分の変動 を良く捉えていた。よって, AMSR-E土壤水分は一 定の精度を持つと考えてよい。

\section{AMSR-E土壤水分の時空間分布}

山西省における月ごとの土壤水分の時空間変動を確 認するために，年間のすべてのデータが含まれる 2003 年から 2009年までの 4 月〜9月について, 7 年間の AMSR-E土壤水分の各月の最大值の平均值を図一 5 に 示した，季節変化については, 4月の土壤水分は全体 に低い值が維持されているが, 5 月から 7 月まで徐々に 上昇し, 8 月に最大值が出現した後, 9月には減少する が，降水量の季節変化パターンと一致している.

空間分布については, Datong, Shuozhou, Xinzhou の西部, Lvliangの西部と Linfenの西部では土壤水分 は低く維持されているが, Changzhi，Jincheng と Yunchengでは土壤水分の変動が大きく, 北西部から 東南部にかけては土壤水分が増加する傾向がある. この分布傾向は図一 4 中に示した山西省における年 平均降水量分布と一致している。全体的な特徵が降 水量の気候学的な分布と一致しているため, AMSR-E土潩水分は広域の状況をよく捉えていると 考えられる.

図一6に地上観測データがある2006年および2007

表 - 1 選択した代表的な 5つの領域の属性（緯度, 経度, 標高, 標高の標準偏差, 平均降水量と土地利用） Table 1 Characteristics (latitude, longitude, elevation, standard deviation of elevation, average precipitation and land use) of five representative areas.

\begin{tabular}{c|c|c|c|c|c|c|c}
\hline コード & 地名 & 緯度 & 経度 & 標高 $(\mathrm{m})$ & $\begin{array}{c}\text { 標高の } \\
\text { 標準偏差 }(\mathrm{m})\end{array}$ & $\begin{array}{c}\text { 平均降水量 } \\
(\mathrm{mm})\end{array}$ & $\begin{array}{c}\text { 主な土地利用 } \\
\text { タイブ }\end{array}$ \\
\hline $\mathrm{a}$ & Datong Xian & 40.00 & 113.60 & 1,023 & 14 & 388 & 高被覆率草地 \\
\hline $\mathrm{b}$ & Meng Xian & 38.00 & 113.35 & 1,177 & 29 & 482 & 有林地 \\
\hline $\mathrm{c}$ & Qingxu Xian & 37.50 & 112.35 & 755 & 9 & 470 & 畑 \\
\hline $\mathrm{d}$ & Guandao Kou & 36.00 & 112.88 & 991 & 19 & 631 & 高被覆率草地 \\
\hline $\mathrm{e}$ & Xu Cun & 35.75 & 111.37 & 456 & 11 & 539 & 高被覆率草地 \\
\hline
\end{tabular}


年の夏季（7月，8月，9月）の各月の初旬の AMSR-E 土壤水分の平均值を示す. AMSR-E土壤水分は7月 から8月にかけて増加し, 9月になると徐々に減少し ている傾向が見られる.AMSR-E土袞水分を空間的
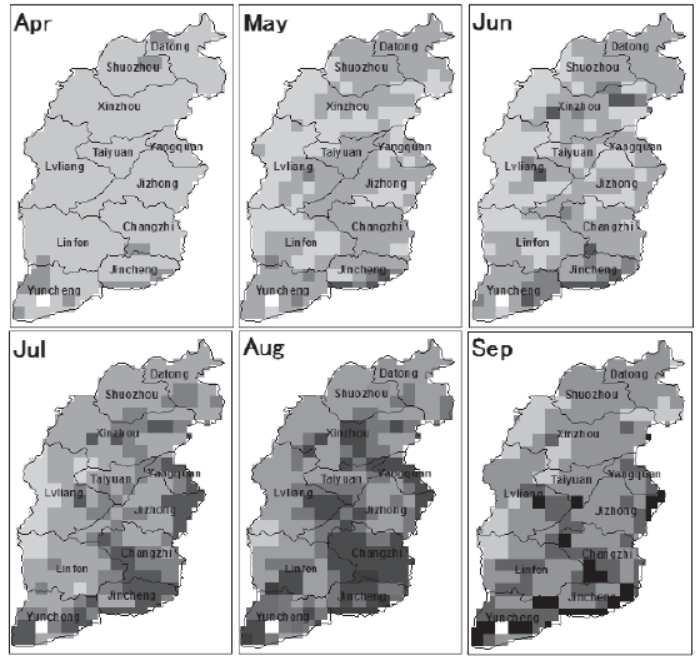

N AMSR.E soll molsture $\left(\mathrm{m}^{2} / \mathrm{m}^{2}\right)$

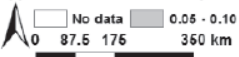

図－5 2003年から 2009年までの4月から 9月の AMSR-E 土壤水分の月最大值の経年平均值の分布

Fig. 5 Monthly (April-September) maximum mean value of AMSR-E soil moisture during 2003-2009.

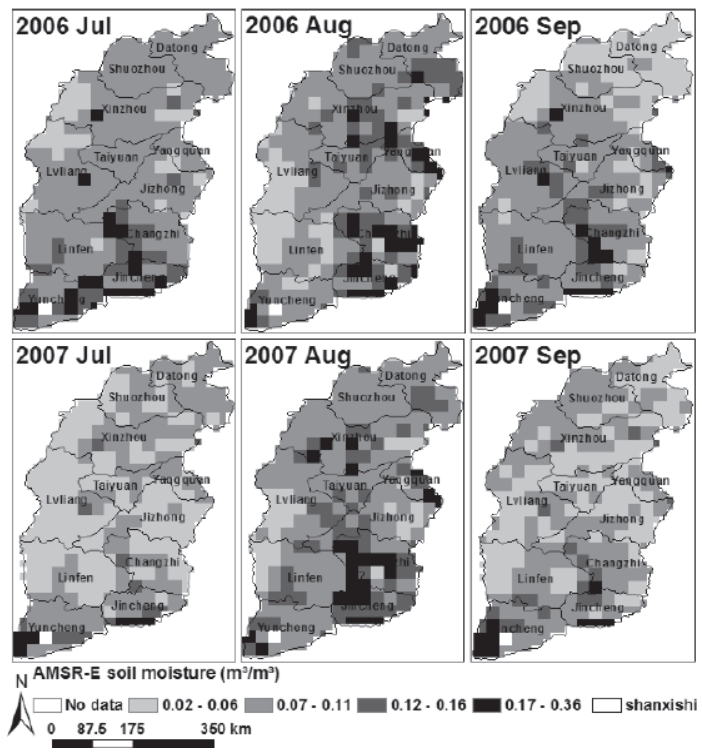

図－6 2006年と 2007 年における夏季（7月, 8 月, 9 月） 初旬の平均の AMSR-E土壤水分の分布

Fig. 6 Mean value of AMSR-E soil moisture for the first 10 days of July, August, and September in 2006, 2007.
に見ると北部（Datong，ShuozhouとXinzhou）は南 部（Yuncheng, Changzhi と Jincheng）より低く，西 部（Lvliang とLinfen）は東部（Yangquan, Jinzhong とChangzhi）より低くなっている。特に南部の Yuncheng盆地地域は全期間を通して, 高い值を維持 している.

日降水量は地表面の土䁃水分の日々変動の重要な 要因である. AMSR-E土壤水分と降水量を比較する ために，同期間（2006年と 2007 年について, 7 月, 8 月と9月の各月の初旬）の降水量の積算値（旬降水 量）を図一7に示した. 2006年および2007年におけ る7月の Taiyuan, Yangquan とXinzhouの西部, 8月の Lvliangの西部とLinfenの西部, 9月の北部Datong, Shuozhou とXinzhouでは旬降水量は少なく, 7月の Yuncheng と Jincheng, 8月の Datong と Shuozhou, 9 月 のLinfen と Yuncheng では旬降水量が多い。図一6に 示したAMSR-E土壤水分の分布と比較すると両者は よく一致しているため, AMSR-E土壤水分は降水に よる地表面の乾湿をよく捉えているといえる。しか し，一致が見られない旬も存在している。例えば, 2006年の8月と2007年 8 月に南部のChangzhi と Jincheng 地域で初旬の降水量の積算値が低い。同時 期のAMSR-E土壤水分は高いが, 中旬は2つの地域 の土壤水分は低い。これは後述の AMSR-E土壤水分
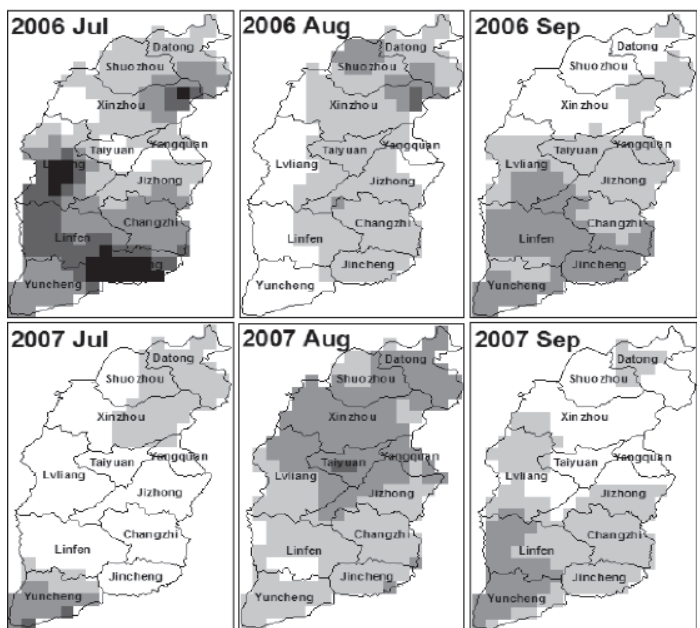

N Precipitation (mm)

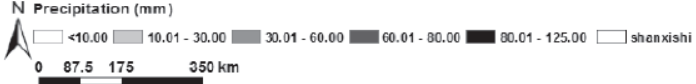

図 -7 2006年と 2007 年の夏季（7月, 8 月, 9月）の各月 初旬の APHRODITE 降水量の積算值

Fig. 7 Integrated value of APHRODITE precipitation for the first 10 days of July, August, and September in 2006, 2007. 
とAPHRODITE 降水量の観測タイミングが異なるこ と，抢よび黄河からの取水による灌溉の影響による 可能性等が考えられるが，今後の検討課題である.

\section{3. 土地利用と土壤水分分布の関係}

図一8は中国 $1 \mathrm{~km}$ メッシュ土地利用デー夕を集成 して作成した 2000 年代の山西省の土地利用図である。 有林地, 高被覆率草地, 畑, 農村居住地, 城鎮用地, 水面の6つの主要な土地利用タイプ（原データの表記 による）ごとに示したが，畑が一番多く分布し，特 に西部を中心に分布していた。すべての盆地（北部 の Datong 盆地, 中部の Taiyuan盆地と Xinding盆地, 南部のChangzhi盆地, Linfen盆地と Yuncheng盆地) でまとまった農村居住地と城鎮用地の分布があるが, これはTaiyuan等の都市域に相当する. Changzhi, Jincheng と Lvliang の東部では有林地と高被覆率草地 の分布が多い，高被覆率草地は Changzhi， Jinchengの 全域と Datong, Xinzhouの東部に分布している。 また, 北部の Datong と Shuozhouでは畑, 農村居住地, 城鎮 用地, 有林地と高被覆率草地など多様な土地利用夕 イプが混在している。そこでは 2 年間の AMSR-E土䁃 水分と実測土壤水分の相関が低いが（相関係数が 0.3 以下)，土地利用の複雑性に関係していると考えられ る。例えば, c（Qingxu Xian）領域で土地利用の夕イ プは畑（87\%), 城鎮用地（12％）とそのほか（1％） であり, 単一の土地利用タイプ (畑) が広く分布し, AMSR-E土壤水分と実測土䁃水分の相関係数は高 かった（0.7以上)。よって，土地利用が均一な地域 ではAMSR-Eは精度を保っていることを示している。

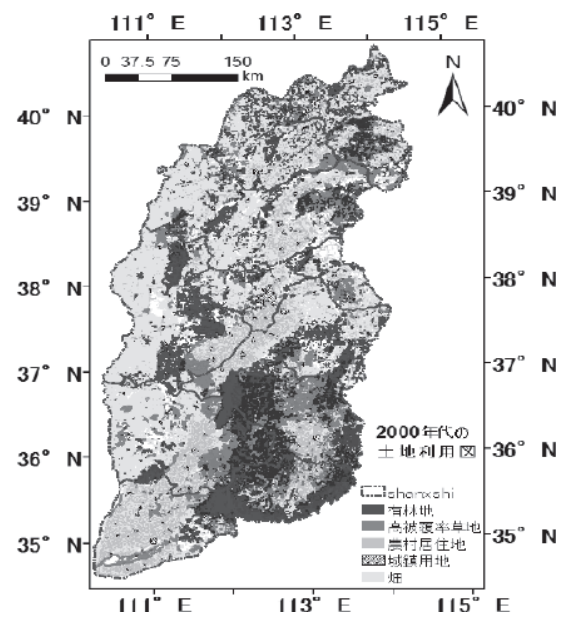

図 -82000 年代の山西省の土地利用

Fig. 8 Land use map of Shanxi Province in 2000s.

\section{4. 降水量と土壤水分分布の関係}

\section{1）日単位の降水量と土壤水分分布の関係}

乾燥・半乾燥地域では, 日単位の土壤水分変動が 大きい。降雨時には直ちに表面の土畩水分が上昇す るが，その後の無降雨期間には蒸発によって土䁃水 分が急速に下がる（篠田, 2005)。図一9は, 2006年7 月28日および29日の AMSR-E土壤水分と APHRODITE 降水量の等值線図である。降水量は28日に北西部 (Shuozhou とXinzhouの西部) で高い值を示すが, 29 日には急激に減少している.29日にShuozhouの南 部，Xinzhouの東部とJinchengの東部で降雨があっ ため, 土壤水分は高い值を示すが, 28 日に土䁃水分 が低い值が示している.APHRODITE降水量が地点 降水量の空間補間で作成されていることを鑑みる と, 降水量と AMSR-E土壤水分の両者の值が高い領 域，および低い領域はほぼ一致している。したがっ て,AMSR-E土壤水分はAPHRODITE 降水量, すな わち降水による表層土壤水分の日レベルのマクロな 時空間分布を捉えていると考えられる。

\section{2）代表領域における降水量と土壤水分の時系列}

選択した 5 領域a (Datong Xian), b (Meng Xian), c (Qingxu Xian), d (Guandao Kou) とe (Xu Cun) に扔 ける2006年および2007年の 4 月から9月の土壤水分

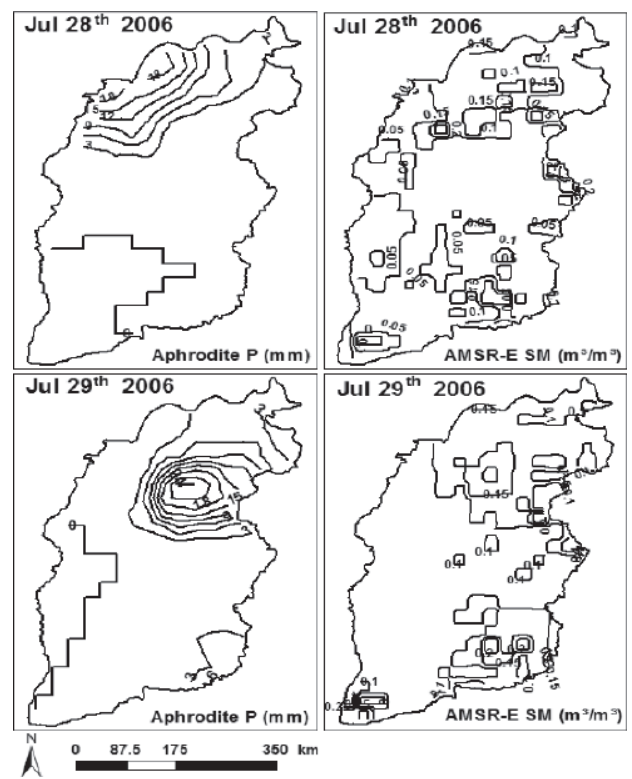

図－92006年7月28日, 29 日におけるAMSR-E土壤水 分とAPHRODITE 降水量の等值線図

Fig. 9 Variation between AMSR-E soil moisture and APHRODITE precipitation on 28 and 29 July 2006. 
と降水量の時系列ダイヤグラムを図ー10に示す。一の変動はほとんど同じ傾向を示し, 降水のイベント 部AMSR-E土壤水分の欠測があるが，全体的に 2 年間とAMSR-E土壤水分のピークは良く一致した。降水
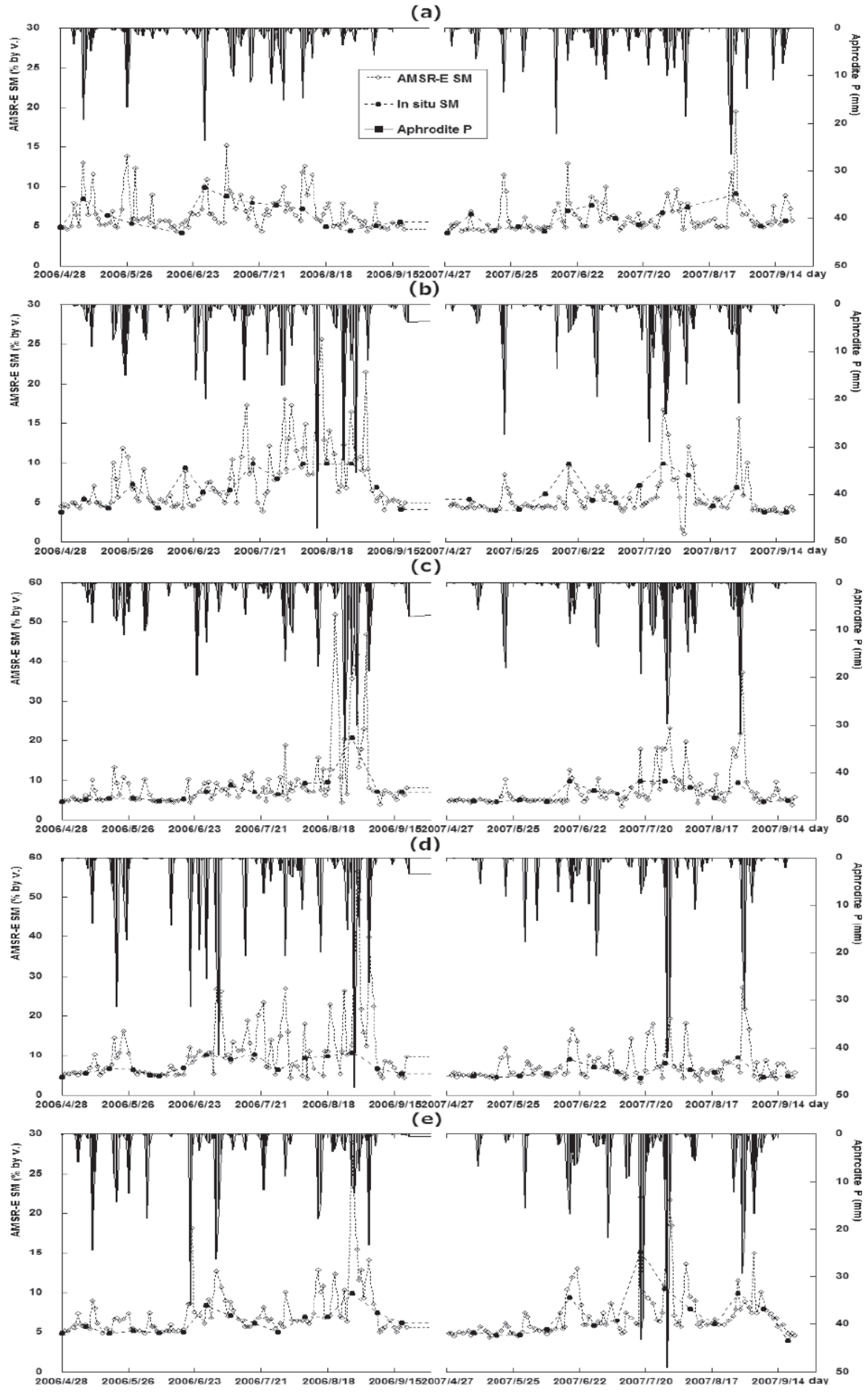

図-10 代表的な 5つの領域におけるAMSR-E土壤水分, 実測值と降水量の時系列変化

Fig. 10 Time series variation among AMSR-E soil moisture, in situ soil moisture and precipitation at five representative areas. 
に対してAMSR-E土畩水分は顕著に大きく変動して いるが，実測值の変動が小さくなっている。また， 無降水時と降水量が $5 \mathrm{~mm}$ 以下の時は, AMSR-E土壤 水分は約 $5 \%$ で一定になっている。降水量が $5 \mathrm{~mm}$ 超えるイベント時において, 土壤水分が増加しなかっ た場合と夕イムラグ（数日程度）が生じる場合があっ た，前者についてはAMSR-Eによる土畩水分観測と 降水のタイミングの不一致が考えられる. AMSR-E 土壤水分は衛星通過時間に打ける瞬間值であるため, 観測後に降水があった場合は日降水量との対応は不 明瞭になる。例えば，図一10に打いて，d（Guandao Kou）では2006年 8 月 7日に抢ける1日降水量の合計 は $10.85 \mathrm{~mm}$ であったが，日中現地時間 13 時半前後に 撮ったAMSR-E土壤水分は低いまま表示された。そ れは現地で衛星を通過した後，降水があったと判断 される，後者の夕イムラグに関しては水が集中する 地形的特性等が考えられるが，地点固有の要因につ いては今後の課題である。

\section{5. 植生指標と土壊水分分布の関係}

\section{1) 時空間分布}

図一 11 に2006年と 2007年の夏季（7月, 8月, 9月） の初旬のNDVIを示す。山西省全域の 7月, 8月, 9月 のNDVIの平均值はそれぞれ $0.49,0.56,0.61$ であり，
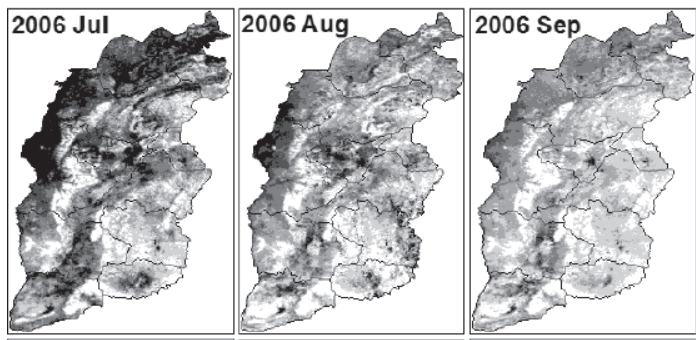

2007 Jul
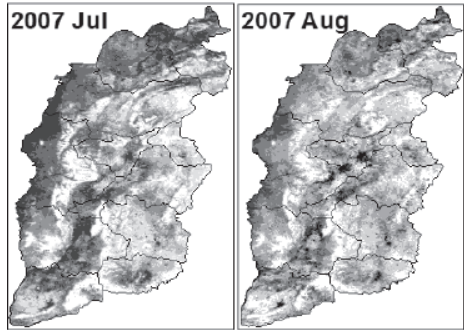

2007 Sep

N NDVI

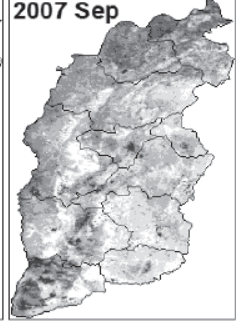

$\Lambda \square<0.30 \square 0.31-0.40 \square 0.41 \cdot 0.50 \square 0.51-0.60 \square 0.61-0.70 \square 0.71-1.00$ $87.5175 \quad 360 \mathrm{~km}$

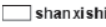

図－11 SPOT/VEGETATIONによる2006年と2007年の 夏季（7月,8月,9月）初旬のNDVIの分布

Fig. 11 Variation of maximum SPOT/VEGETATION NDVI for the first 10 days of July, August and September in 2006, 2007
増加している傾向が見られる. 中部の Taiyuan盆地, Lvliangの西部，南部のLinfen盆地と Yuncheng盆地で はNDVIが低い值を維持し, Changzhi 地域と Jincheng 地域ではNDVIが高いことを示す。それは図一6に示 したAMSR-E土䁃水分の空間分布とよく対応する。 NDVIは全体的に北から南まで，西から東に向かっ て徐々に増加している特徵が見られたが，AMSR-E 土壤水分とNDVIが合っていない場所も存在する。 例えば, Lvliangの東部では植生被覆率が多く分布し, AMSR-E土壤水分は高い值が得られなかった。この ことは密な植生域ではAMSR-Eによる土䁃水分観測 が難しいことを裏付けている（小池ほか, 2000）.

\section{2）代表領域における NDVI と土壤水分の比較}

代表領域に打ける2006年と2007年のAMSR-E土 壤水分とNDVIの関係を図一12に示す。その中のb (Meng Xian) では高い相関係数（0.92）が得られた. 土地利用は有林地のため, 植生の生育の指標である NDVIが大きく, NDVIを通して間接的に土壤水分を
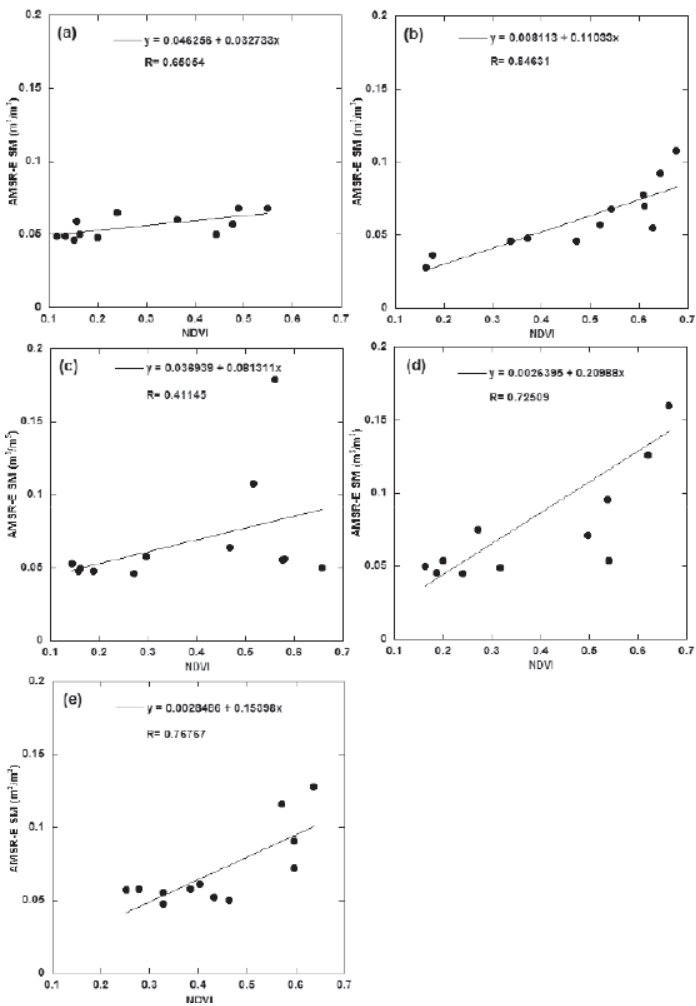

図-12 山西省における代表的な 5つの領域の AMSR-E 土壤水分と NDVIの関係

Fig. 12 Relation of AMSR-E soil moisture to NDVI at five representative areas of Shanxi Province. 
見ていることになる。a (Datong Xian), d（Guandao Kou）と e (Xu Cun) では土地利用が高被覆率草地 であり，NDVIと土壤水分の間に良い相関（相関係 数は $0.67 〜 0.78$ ）が得られた. c（Qingxu Xian）で

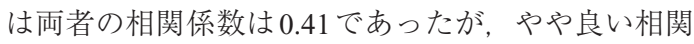
が得られた。それはc領域では畑に覆われ5月から9 月まではトウモロコシの生育期間のため, NDVI変 化が大きいことを影響されると考えられた。

\section{V。おわりに}

AMSR-E土畩水分データの精度検証を行うため に, 中国の山西省における実測土壤水分が利用可能 な2006年と 2007 年の4月 28 日から9月 18 日につい て, 相関の検討した。 土壤水分測定日の実測值と AMSR-E土畩水分の相関を検討したところ, 108 力所 の地上観測地点のうち 64 力所において 0.5 以上の相 関係数が得られた。 中部の Taiyuan盆地, 南部の Linfen盆地, Yuncheng盆地, Changzhi盆地と Jincheng 地域, 東部の Yangquan 地域では2006年, 2007 年とも に高い相関係数は 0.7 を超えたが, 北部のDatong 地 域と Shuozhou地域では相関が低かった（0.3以下）. 相関の高い地点は, 1) 十分な密度の地上観測地点が ある地域, 2) 土地利用夕イプが均一な地域, 3) 地形 が相対的に平坦な地域であった。これらの条件を満 たす地域ではAMSR-E土壤水分は実測值と相関が高 いことから, AMSR-E土壤水分データは一定の精度 を持つと考えられる.

土壌水分の季節変動および広域の空間分布の観点 から AMSR-E土壤水分を検証するために, 山西省に おけるAMSR-E土壤水分と降水量の時空間分布の比 較を行った. AMSR-E土壤水分の季節変化としては 夏に高い值を示したが, これは降水量の季節変化と 一致する．空間的には山西省の北西部から南東方向 に值が増加している傾向を確認したが，降水量の空 間分布と整合的であり，AMSR-E土䁃水分は広域の 地表面の乾湿をよく捉えていると考えられた.

AMSR-E土壤水分と植生指標 (NDVI) の関係につ いては, 山西省全体における分布傾向は同様な時 間・空間分布を示し，植生が活発な地域では両者の 相関係数が高いことを確認したが, 高密度森林地域 ではAMSR-E土潩水分の精度が若干落ちることが分 かった。 土壤水分とNDVIの因果関係については今 後の検討課題であり, 植生の生育型ごとに解析する 必要があろう。
以上の結果から AMSR-E土壌水分データは土壤水 分の時間変化および空間分布を良く捉えていると考 えられるが, 土地利用が混在する地域, 地形の起伏 が大きい地域, 森林地域では推定精度が若干落ちる 可能性があるため, AMSR-E土壤水分の扱いには注 意すべきである，今後は，以上の結果に基づいて， 東アジアにおける土壤水分の時空間変動について解 析を試みる予定である。

\section{謝辞}

本研究で利用したAMSR-E土壤水分データの開発 グループには心より御礼申し上げます。千葉大学の 近藤研究室の先輩の方々には, 研究作業の過程にお いて貴重なご助言を多く頂きました。これらの方々 に深く感謝いたします。また，留学生活に支えてい る家族に心から感謝しています.

\section{引用文献}

Jackson TL. 1993. Measuring surface soil moisture using passive microwave remote sensing. Hydrological Processes 7 (2): 139-152. DOI: 10.1002/hyp. 3360070205.

Kaihotsu I, Koike T, Yamanaka T, Fujii H, Ohta T, Tamagawa K, Oyunbaatar D, Akiyama R. 2009. Validation of soil moisture estimation by AMSR-E in the Mongolian Plateau. Journal of the Remote Sensing Society of Japan 29 (1): 271281.

小池俊雄・下茂 カ・太田 哲.藤井秀幸・柴田 彰 2000. 陸面水文 量分布のグローバル推定のためのマイクロ波放射計アルゴリズム の開発と検証. 水工学論文集 B 44: 247-252. DOI: 10.2208/ prohe.44.247.

小池俊雄· 中村佳照·開發一郎· Gombo Davaa - 松浦直人.玉川勝 徳・藤井秀幸 2004. 改良型高性能マイクロ波放射計 (AMSR-E) による土壤水分・植生水分観測手法の開発. 水工学論文集 B 48: 217-222. DOI: 10.2208/prohe.48.217.

道浦俊夫 2011. “改良型高性能マイクロ波放射計 (AMSR-E) の現 状とこれまでの成果について”, 宇宙航空研究開発機構 (JAXA), http://www.jaxa.jp/press/2011/10/20111012_sac_AMSR-E_ j.html. (参照:2014/10/20)

牛俊杰. 趙 景波 2008. 山西省土壤水環境および植生建設. 中 国環境科学出版社; 10-29. (中国語)

Njoku EG, Jackson TL, Lakshmi V, Chan T, Nghiem SV. 2003. Soil Moisture Retrieval from AMSR-E. IEEE Transactions on Geoscience and Remote Sensing 41(2): 215-229. DOI: 10.1109/TGRS.2002.808243.

Owe M, de jeu R, Walker J. 2001. A methodology for surface soil moisture and vegetation optical depth retrieval using the microwave polarization difference index. IEEE Transactions on Geoscience and Remote Sensing 39 (8): 1643-1654. DOI: $10.1109 / 36.942542$.

篠田雅人 2005. 乾燥地域における土壤水分メモリーその機能と研 究の意義一. 日本砂漠学会 14 (4) :185-197. DOI: 10.2208/prohe. 44.247.

Yatagai A, Arakawa O, Kamiguchi K, Kawamoto H, Nodzu M, Hamada A. 2009. A 44-year daily gridded precipitation 
dataset for Asia based on a dense network of rain gauges. SOLA 5: 137-140. DOI: 10.2151/sola, 2009-035.

Yatagai A, Kamiguchi K, Arakawa O, Hamada A, Yasutomi N, Kitoh A. 2012. APHRODITE: Constructing a long-term daily gridded precipitation dataset for Asia based on a dense network of rain gauges. Bulletin of the American Meteorological
Society 93 (9): 1401-1415. DOI: 10.1175/ BAMS-D-11-0 0122.1.

(受付：2015年 5 月 29 日, 受理：2015年 12 月 3 日)

この論文への討議・コメントを, 2017年1月末日 まで受け付けます。

\title{
Spatiotemporal variations of AMSR-E Soil Moisture in Shanxi Province, China
}

\author{
Mei SUN ${ }^{1)} \quad$ Likun AI $^{2)}$ Ichirow KAIHOTSU ${ }^{3)}$ Hideyuki FUJII ${ }^{4)}$ Akihiko KONDOH 5) \\ 1) Graduate School of Science, Chiba University, Japan \\ (1-33 Yayoi, Inage, Chiba-Shi, Chiba, Japan) \\ 2) Institute of Atmospheric Physics, Chinese Academy of Sciences \\ (No.40, Huayanli, Beichen West Street, Chaoyang District, Beijing, China) \\ 3) Graduate School of Integrated Arts and Sciences, Hiroshima University, Japan \\ (1-7-1 Kagamiyama, Higashihiroshima-Shi, Hiroshima, Japan) \\ 4) Remote Sensing Technology Center of Japan \\ (3-17-1 Toranomon, TOKYU REIT Toranomon-building 3F, Minato-Ku, Tokyo, Japan) \\ 5) Center for Environment Remote Sensing, Chiba University, Japan \\ (1-33 Yayoi, Inage, Chiba-Shi, Chiba, Japan)
}

Soil moisture is a crucially important hydrological element that is closely connected to the earth's surface heat budget and climate change in semi-arid and arid regions. Recently, satellite remote sensing has been demonstrated as an effective means of determining soil moisture in large areas over long time periods. AMSR-E soil moisture measurements derived from passive microwave time-series data are available. This study was conducted to validate AMSR-E soil moisture data using in situ soil moisture measurements and to ascertain the relation among soil moisture, hydrological factors (precipitation), and vegetation (NDVI) in Shanxi Province, China. Results show that 64 of 108 in situ stations exhibit good correspondence between AMSR-E soil moisture and in situ soil moisture. Furthermore, high correlation coefficients were found for measurements taken in the following three conditions: 1) sufficient density of in situ observation areas, 2) uniform land use type region, and 3) flat terrain area. Consideration of those three factors can raise the accuracy of estimation for AMSR-E soil moisture in large regions.

Key words : AMSR-E, soil moisture, precipitation, Shanxi Province 